\title{
Mediating role of Affective Organizational Commitment on the Relationship between Training and Employee's Performance: A case of Civil Society Organizations
}

\author{
Ayesha Abbas ${ }^{a}$, Nargis Abbas ${ }^{b}$, Uzma Ashiq ${ }^{c}$, Farhat Abbas ${ }^{\text {d }}$ \\ ${ }^{a}$ Leads Business School, Lahore Leads University, Lahore, Pakistan \\ ${ }^{\mathrm{b}}$ Department of Education, University of Sargodha, Pakistan \\ Email: nargis.abbas@uos.edu.pk \\ ${ }^{c}$ Department of Social Work, University of Sargodha, Pakistan \\ Email: uzma.ashiq@uos.ed.pk \\ ${ }^{\mathrm{d}}$ Department of Education, University of Sargodha, Pakistan
}

\begin{tabular}{|c|c|}
\hline ART & ABSTRACT \\
\hline Hist & \multirow{11}{*}{$\begin{array}{l}\text { In a competitive business environment, organizational performance } \\
\text { depends upon employees' performance and their capabilities, which can } \\
\text { be enhanced through effectual tools like, trainings to boost knowledge, } \\
\text { behaviour and skills of employees etc. This research aimed to investigate } \\
\text { the effect of training on employees' performance directly and indirectly } \\
\text { mediated through affective organizational commitment in the civil } \\
\text { society organizations of Pakistan. The convenient Sampling technique } \\
\text { was used and the sample of } 219 \text { employees was selected out of } 569 \text { total } \\
\text { employees from different CSOs Offices of the Punjab with the help of } \\
\text { Krejcie and Morgan table. Descriptive statistics, correlation and } \\
\text { confirmatory factor analysis were used to the data. The results } \\
\text { demonstrated that training had a positive and significant impact on } \\
\text { employees' performance. Further, affective organizational commitment } \\
\text { was found to have a significant mediation in the relationship between } \\
\text { employees' performance and training. Thus, the study suggested that } \\
\text { training should be the part of civil society organization to boost the } \\
\text { organizational commitment which will affect the employee performance. }\end{array}$} \\
\hline Acce & \\
\hline C 2020 & \\
\hline Key & \\
\hline Tra & \\
\hline Perfo & \\
\hline $\begin{array}{l}\text { ommitment, } \\
\text { ociety }\end{array}$ & \\
\hline Orgat & \\
\hline & \\
\hline & \\
\hline & \\
\hline
\end{tabular}

(C) 2020 The authors. Published by SPCRD Global Publishing. This is an open access article under the Creative Commons Attribution-

NonCommercial 4.0

Corresponding author's email address: nargis.abbas@uos.edu.pk

\section{Introduction}

Currently business environment is promptly varying. In advance business world, activities of the organizations are aimed to the planned goals and to accomplish them by increasing their resources including human resource, money and material. Human resource is the most essential asset of an organization (Liu, 2006). Organization is a place where a group of people gather to achieve the combined/ 


\section{Review of Economics and Development Studies, Vol. 6 (4) 2020, 867 - 879}

common objectives. Organizations have main infrastructure and human resource which may contribute a lot to the performance, productivity or output of a particular organization.

For excellent effectiveness, organizations require to build the capacities of manpower and increase their potential. Capacity is the ability to achieve desired goals effectively and efficiently by individuals, groups or at organizational level by performing specific tasks (Krishnavani \& Sujatha, 2012) and training is the most appropriate practice used to build the capabilities of employees. To enhance the employee's working skills, abilities, and behaviour, training has been considered one of the main factors (Farooq \& Khan, 2011). Thus, organizations encourage their employees for continuous training programs according to the need of the working environment and tasks. It is argued that an organization can sustain at top ranking among the organizations through the selection of quality human resource and boosting professional training to the employees.

Organizations used several human resource strategies and approaches to achieve their desired goals and one of the best approaches is the commitment strategy, attempt to build up the psychosomatic associations between the employees and company as a mean of achieving goals (Brum, 2007). Organizational commitment strengthens the individual's recognition and participation in a specific organization (Imran, 2012). Thus, the work outcomes can be improved by increasing the employee's commitment. According to Yeh and Hong (2012), organizational commitment can enhance overall the organizational competitiveness and performance of an employee. Therefore, when the employees share the sense of belongingness and hold identification, they become more associated with the organization and more passionate to achieve the organizational goals (Shahid \& Ali, 2019).

CSOs are those non- governmental organizations, which deal the project on national level. The CSOs employees are engaged with different kind of projects that are required to be completed within the specified time period. These diverse projects call for specific skills and know how to perform the project related tasks. The employees thus need training if the project requires a different skill set or know how. Consequently, training is a strategic tool to build employees required skills and make them more committed and strongly associated with the organizations.

As noted above, training is the most effectual tool for the improvement of interpersonal skills of employees. In human resource practices, training is the best approach which has the strongest impact on organizational profitability, therefore organization's performance and productivity is increased by increasing the training programs (Aragon \& Valle, 2013). All employees focus to improve their present skills and learn new skills to do the tasks in adequate manner and for this sake they obtain more and more training in their career (Giangreco et al., 2009). Training is most essential practice for new employees because employees are the indispensable asset for the organizations and for this sake organizations spend huge amount of money on employees' need base training to enhance their performance and increase their commitment level with the organization (Falola et al., 2014). Moreover, training is systematic and formal technique to modify the behaviour of employees during learning which may occur in the form of planned experiences, instruction, improvement and education (Jager, 2012).

In the past decades it has been admitted that human resource is the main key of an organizational success. Every organization has many departments, which comprise of a large number of workers having different temperament, attitude, behaviour, experience, thoughts, habits and even cultures. With these individual differences, they all are indulged to achieve the specific task efficiencies keeping in view their own limitations to handle the said objective. In addition, not every worker can tackle the verity of task until they have much knowledge, ability and expertise about various kinds of tasks (Farooq \& Khan, 2011). Performance of a skilled employee plays a big role in the productivity of an organization by accomplishing the organization's expectations, needs and requirements (Folorunso et al., 2014). 


\section{Review of Economics and Development Studies, Vol. 6 (4) 2020, 867 - 879}

However, employee's productivity and performance can be enhanced through an effectual training activity. Its' only purpose is not to enhance the performance of an employee but also provide the new opportunity to show their competencies and their ability to achieve the desired goals. Thus, it is a useful technique to build the teamwork, enhance decision making power and problem-solving capabilities in employees and thus have a strong impact on organizational performance (Nda \& Fard, 2013). Employees' performance enhances if the suitable training programs are conducted._William and Anderson (1991) worked on task performance, which is defined as behaviour related to satisfying and examining the specified task of an organization. Therefore, job training is necessary for employees and it reduces cost and save time. During the training session, junior employees attached to their seniors to learn new competencies and skills which eventually help them to perform better for assigned tasks (Ahmad et al., 2014).

The commitment is an internal state of feelings, wishes and behaviour of a person, which refers to a state of genuineness to do something. Therefore, organizational commitment can be understood as the association between organizations and individuals (Khan et al., 2014). Several researchers contributed in developing the concept of organizational commitment. It is the psychosomatic attachment with the organizations which determine the affection toward the organization relying on the rate of an individual's commitment (Akhtar, 2014; Imran, 2012; Gardner et al., 2011). Organizational commitment can be categorized in three factors such as (a) a strong belief, and acceptance of the organizational goals and norms, (b) a willingness to apply great effort on behalf of the organization, and (c) a strong wish to remain a part of the organization (Jaros, 2007; Conway, 2003; Chen, 2004).

Various researchers revealed that affective commitment is the most common type of organizational commitment in which employees emotionally attached to the organization and strongly committed to achieve the organizational goal and also enjoys the membership with the organization (Lamba \& Choudhary, 2013; Allen \& Meyer, 1990).

Organizational commitment is just like a bond between employee and the organization therefore, employees emotionally attached to the organization where they work, and researcher focused on the affective commitment (Restubog et al., 2006). Chen (2004) and Lamba \& Choudhary (2013) researched on affective commitment and found its positive correlation with the job performance. Similarly, Koc et al. (2014) worked on HRM practices like training and development, selection, rewards, performance assessment, job satisfaction and organizational commitment. They examined that employees who were aware of the organizational goals and competitiveness were more committed to the organization and performed their duties with loyalty and liability. On contrary, those employees who were not satisfied with their jobs couldn't perform their duties well and remained engaged in negative behaviour, like absenteeism, which showed their lower commitment towards the organization. Mahmood (2012) investigated the mediation role, as organizational commitment and employee retention mediate between the training and employee's performance. Author selected 400 samples from service sector and used correlation and regression to analyze the data and concluded that organizational commitment played partially mediate between training and employee performance.

Most of researchers conducted the research to examine the impact of training on employees' performance in various sectors like education sector, service sector, hotel industry etc. (Imran, 2012; Ameeq \& Hanif, 2013), however, there is a scarcity of research that has been conducted in civil society organizations. Therefore, the purpose of this paper was to investigate the impact of training on the performance of employees in the presence of affective organizational commitment. The central research question was, whether training influences significantly the employees' performance in CSOs context. Moreover, does organizational commitment mediates the relationship between training and employees' performance. 


\section{Hypothetical Model and Research hypotheses}

The proposed diagram describes the relationship of training with employees' performance and affective organizational commitment. The conceptual framework was adopted Mahmood (2012) used the organizational commitment as mediator in training and employee performance. Hence, the proposed conceptual framework is given below.

Figure 1: Hypothetical model of the study

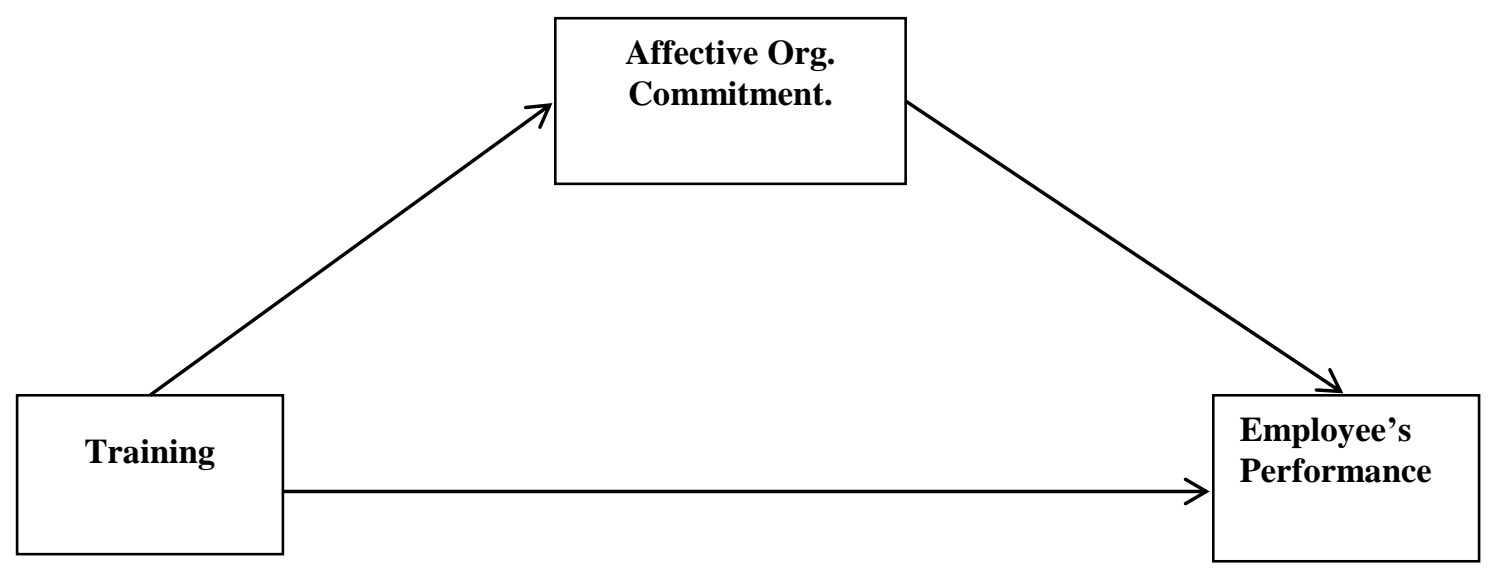

According to the aforementioned research question in literature review, following hypotheses were formulated.

$\mathrm{H}_{1}$ : There is a significant direct effect of the training on the employee's performance in CSOs.

$\mathrm{H}_{2}$ : Affective Organizational commitment significantly mediates the relationship between training and employee's performance.

\section{Research Methodology}

A quantitative survey research design was adopted. The convenient Sampling technique was used and the sample of 236 employees was selected out of 569 total employees from different CSOs offices of the Punjab by using Krejcie and Morgan table. The inclusion criterion for selecting the employee was their training in last one year. The data were collected through well-structured questionnaire. Out of 236 questionnaires obtained from respondents, 17 questionnaires were dropped due to incomplete information or non-filled questionnaires. Thus, the final sample size was 219.

Research instrument was comprised of two sections, the first section was comprised of the demographic profile of the respondents and the second section was consisted of the scales to measure the variables of the study. All the items were rated on 5-points likert scale ranging from " 1 " (strongly disagree) to "5" (strongly agree). To measure the variable "Training", a 12 items scale was adopted from Abbad et al. (2004). Examples of the scale are "The quality of the work I do have improved" and "I do my work faster" etc. Further, the variable "Employees' performance" was measured through 8 items scale, developed by William and Anderson (1991), was adopted. Examples of the scale are "Complete the tasks assigned to me within the allotted time" and "Always complete all aspects of my own basic duties" etc. The third variable "Affective Organizational Commitment" was measured through 8 items scale constructed by Allen \& Meyer, (1990). Examples of the scale are "I enjoy discussing about my organization with people outside it" and "I would be very happy to spend the rest of my career with this organization".

A pilot test was conducted on 30 respondents to measure the reliability of this research instrument (Hertzog, 2008; Hill, 1998; Isaac \& Michael, 1995). Cronbach' Alpha was used to measure the internal consistency and reliability of the instrument. Alpha value ranges from 0 to 1 but most satisfactory value considered more than 0.6 for scale to be reliable (Alzalabani \& Modi, 2014). The reliability of the scale of 
Review of Economics and Development Studies, Vol. 6 (4) 2020, 867 - 879

the variable "Training" at $\alpha=0.768$, for the outcome/dependent variable "Employee's performance' was measured at $\alpha=0.802$ and for mediating variable "Affective Organizational commitment" was found at $\alpha=0.931$.

\subsection{Data Analysis}

To analyse the data, frequencies, descriptive statistics and CFA-SEM were performed to examine the mediating effect of affective organizational commitment on the relationship between training and employee performance.

\subsubsection{Demographic information of the respondents}

In this section, we explored demographic information. According to the first part regarding demographic information, five major questions were asked to the respondent (age, gender, education level and working experience of the respondent in current organization). The percentage and frequencies of these variables are given in following table 1.

Table 1. Demographic information of the Respondents

\begin{tabular}{|l|l|}
\hline Demographic Variables & Frequency (\%) \\
\hline Gender & \\
\hline Female & $106(48.4 \%)$ \\
\hline Male & $113(51.6 \%)$ \\
\hline Age & \\
\hline Less than 25 years & $41(18.7 \%)$ \\
\hline $25-35$ years & $116(53 \%)$ \\
\hline $35-45$ years & $50(22.8 \%)$ \\
\hline More than 45 years & $12(5.5 \%)$ \\
\hline Highest level of education? & \\
\hline Higher secondary school & $15(6.8 \%)$ \\
\hline Graduation & $97(44.3 \%)$ \\
\hline Masters & $82(37.4 \%)$ \\
\hline MS/PhD & $25(11.5 \%)$ \\
\hline How long have you been in current organization? & \\
\hline Less than one year & $45(20.5 \%)$ \\
\hline 2-4 years & $120(54.8 \%)$ \\
\hline $5-7$ years & $45(20.5 \%)$ \\
\hline More than 7 years & $09(4.1 \%)$ \\
\hline Trainings attended by the Respondents & \\
\hline One training & $48(21.9 \%)$ \\
\hline $2-4$ trainings & $133(60.7 \%)$ \\
\hline More than 4 trainings & $38(17.4 \%)$ \\
\hline
\end{tabular}

Table 1 show the distribution of respondents with respect to gender, with 113 males (51.6\%) and 106 females $(48.4 \%)$, is a gender balanced sample. Next level shows the age distribution of the sample. Age distribution shows that $18.7 \%$ respondents were less than 25 years and the largest percentage $53 \%$ respondents were in the age group of 25- 35 furthermore $22.8 \%$ having age between $35-45$ and the lowest percentage of respondents that is $5.5 \%$ belongs to more than 45 years. In the next level, table 1 shows the distribution of the sample relating to educational qualification. Only $6.8 \%$ respondents fall in the first category. $44.3 \%$ respondents were having a bachelor's degree and $37.4 \%$ and $11.5 \%$ have a Masters' Degree and $\mathrm{MS} / \mathrm{PhD}$ degree respectively. It showed that the respondents of the study having a higher 
secondary school education were smallest group, whereas, the largest percentage group was Master Degree holders.

In order to study the working experience as well as their affiliation with the current organization, a question "For how long you are working in the current organization?" was asked. Table 1 show that $20.5 \%$ had less than one-year experience and $54.8 \%$ of the respondents were having 2-4 years of experience, whereas $25 \%$ of the respondents were having more than 5 years of experience which showed that the respondents of the study were experienced in their field.

Last question was about the number of training to highlight their training experience. Results described that $21.9 \%$ had only one training and $60.7 \%$ mentioned 2 to 4 trainings which is largest group. While, $17.4 \%$ mentioned to have more than 4 trainings in their career, which is the smallest group of the respondents.

The main objective of this paper was to investigate the mediation of organizational commitment, therefore correlation among the variables were measured.

Table 2: Means, SD and Correlation coefficients among the variables

\begin{tabular}{|l|l|l|l|l|l|l|}
\hline Variables & $\mathbf{N}$ & Mean & SD & $\mathbf{1}$ & $\mathbf{2}$ & $\mathbf{3}$ \\
\hline Training of Employee & 219 & 3.98 & 0.4531 & 1 & & \\
\hline Organizational Commitment & 219 & 3.47 & 0.5355 & $0.410^{* * *}$ & 1 & \\
\hline Employee's Performance & 219 & 3.91 & 0.577 & $0.572^{* * *}$ & $0.407^{* * *}$ & 1 \\
\hline
\end{tabular}

$* * * \mathrm{p}<0.001$

Table 2 shows the simple means, standard deviation and correlation coefficient of all variables under analysis. The mean values of the variables were ranging from 3.4 to 3.98 on a 5-points Likert scale. All the means are fairly high which indicated that respondents have shown positive level of agreement towards the variables. In addition, the small values of standard deviation against each variable indicated that there was no so much variation in the data. Further, the correlation values among the independent, dependent variable and mediator were calculated. The $\mathrm{p}$ values indicated that all the variables were significant and positively correlated $(\mathrm{p}=.000)$. It was found that "Training" was significantly positive correlated with the "Employee's Performance" ( $r=0.572, p<0.001)$. Further, the correlation coefficient of "Training" with mediator "Organizational commitment" was also found significant and positive $(r=0.410, p<0.001)$. Similarly, the "Organizational commitment" and "Employee's Performance' were found to have significant positive correlation between them ( $\mathrm{r}=0.407$, $\mathrm{p}<0.001)$.

The next step was to perform the confirmatory factor analysis (CFA), for this, AMOS v.20 was used. To investigate the capacity of the measurement model for predicting the regression coefficients of the causal relationships, the significance of the loading for each item of the scales was investigated in the table 3. 
Table 3: Loadings of the measurement model

\begin{tabular}{|c|c|c|c|c|}
\hline Variables & Items & $\mathbf{R}^{2}$ & Factor Loadings & t-values \\
\hline \multirow{12}{*}{ Training } & TR1 & .25 & $.502^{* * *}$ & 5.482 \\
\hline & TR2 & .27 & $.519 * * *$ & 5.579 \\
\hline & TR3 & .41 & $.634^{* * *}$ & 6.268 \\
\hline & TR4 & .41 & $.643^{* * *}$ & 6.309 \\
\hline & TR5 & .04 & $.186^{*}$ & 2.418 \\
\hline & TR6 & .17 & $.406^{* * *}$ & 4.698 \\
\hline & TR7 & .27 & $.518 * * *$ & $5 \cdot 574$ \\
\hline & TR8 & .11 & $.311^{* * *}$ & 3.824 \\
\hline & TR9 & .31 & $.556^{* * *}$ & 5.819 \\
\hline & TR10 & .22 & $.472^{* * *}$ & 5.245 \\
\hline & TR11 & .19 & $.434^{* * *}$ & 4.951 \\
\hline & TR12 & .24 & $.492^{* * *}$ & 5.390 \\
\hline \multirow{8}{*}{$\begin{array}{l}\text { Organizational } \\
\text { Commitment }\end{array}$} & OC1 & .55 & $.744^{* * *}$ & 8.401 \\
\hline & OC2 & .60 & $.775^{* * *}$ & 10.698 \\
\hline & $\mathrm{OC}_{3}$ & .54 & $.738^{* * *}$ & 10.227 \\
\hline & $\mathrm{OC}_{4}$ & .01 & .118 & 1.615 \\
\hline & $\mathrm{OC}_{5}$ & .03 & $.160^{*}$ & 2.198 \\
\hline & OC6 & .13 & $.349^{* * *}$ & 4.804 \\
\hline & $\mathrm{OC}_{7}$ & .47 & $.689 * * *$ & $9 \cdot 561$ \\
\hline & OC8 & .09 & $.299 * * *$ & 4.101 \\
\hline \multirow{7}{*}{$\begin{array}{l}\text { Employee's } \\
\text { Performance }\end{array}$} & EP1 & .38 & $.613^{* * *}$ & 6.842 \\
\hline & EP2 & .40 & $.633^{* * *}$ & 7.528 \\
\hline & $\mathrm{EP}_{3}$ & .23 & $.483^{* * *}$ & 6.064 \\
\hline & $\mathrm{EP}_{4}$ & .40 & $.632 * * *$ & 7.518 \\
\hline & $\mathrm{EP}_{5}$ & .56 & $.747^{* * *}$ & 8.460 \\
\hline & EP6 & .30 & $.546^{* * *}$ & 6.712 \\
\hline & EP7 & .31 & $.553^{* * *}$ & 6.778 \\
\hline
\end{tabular}

Three latent variables were fitted in the conceptual model along with their items to perform the CFA. The regression coefficients (which are the loadings of the items) of each item measuring its respective latent variable were analysed on 95\% confidence interval. The results in table 3 showed that all factor loadings of the items with respect to their latent variables were significant at $\alpha=0.05$ except for OC4 which was found non-significant. This item was deleted from the model and rerun the CFA to improve the model. $\mathrm{R}^{2}$ measures the variance of the items explained by the latent variables also considered as a "traditional non-SEM path model-fit index" (Schumacker \& Lomax, 2004, p.159).

\subsection{Model Testing}

In the model testing process, data is verified for the structural model. How well the data fit in the model means to check whether the hypothesized structural model is consistent with the data collected following the respective theory or conceptual framework (Abbas et al., 2020). The overall goodness of the fit is measured by chi-square. However, due to its sensitivity to the sample size there are varieties of goodness-of-fitness indices which aid the chi-square statistic. These two classes of indices i.e incremental and absolute indices (Bollen, 1989; Byrne, 2006). Absolute fit indices measure the extent to which specified model reproduces the sample covariance matrix (Lei \& Wu, 2007, p.37). It includes Chi-square, Normed 
Review of Economics and Development Studies, Vol. 6 (4) 2020, 867 - 879

Chi square (CMIN/DF) and Root Mean square error of approximation (RMSEA) (Bahoo et al., 2020; Steiger \& Lind, 1980). Whereas, the incremental fit indices, for example CFI, measure the increase in fit relative to a baseline model (Bentler, 1990; Bollen, 1990).

Therefore, before studying the mediating role of affective organizational commitment on the relationship between training and employee's performance, it is pertinent to test the model for goodness-offit. The normed chi-square $(\mathrm{CMIN} / \mathrm{DF}) \chi^{2}$ (normed) $=2.319$, was found within the range. The acceptable range for normed chi-square is between 1 and 3 (Abbas, 2011; Hair et al., 2009; Kline, 2005), sometimes less than 5 is also accepted (Schumacker \& Lomax, 2004). The calculated value of the normed chi square for the structural model of the study ensured that the model fits the data well. The Root Mean square error of approximation (RMSEA) value was measured at 0.081, which was less than 0.1, found in acceptable range (Sanei \& Poursalimi, 2018; Loehlin, 2004). Further, the important incremental statistics of the model is comparative fit index (CFI). The standard range of the values for the incremental fit indices is " 0 to 1 ", the value closer to 1 is considered as good fit (Byrne, 2006). The CFI was found at 0.89 which is approaches to 1 thus considered as acceptable. Lastly, the Parsimony normed fit index (PNFI), which ranges between 0 and 1 , value closer to 1 is a good fit, here its value was found 0.748 .

Figure 2. Structural Model with path coefficients

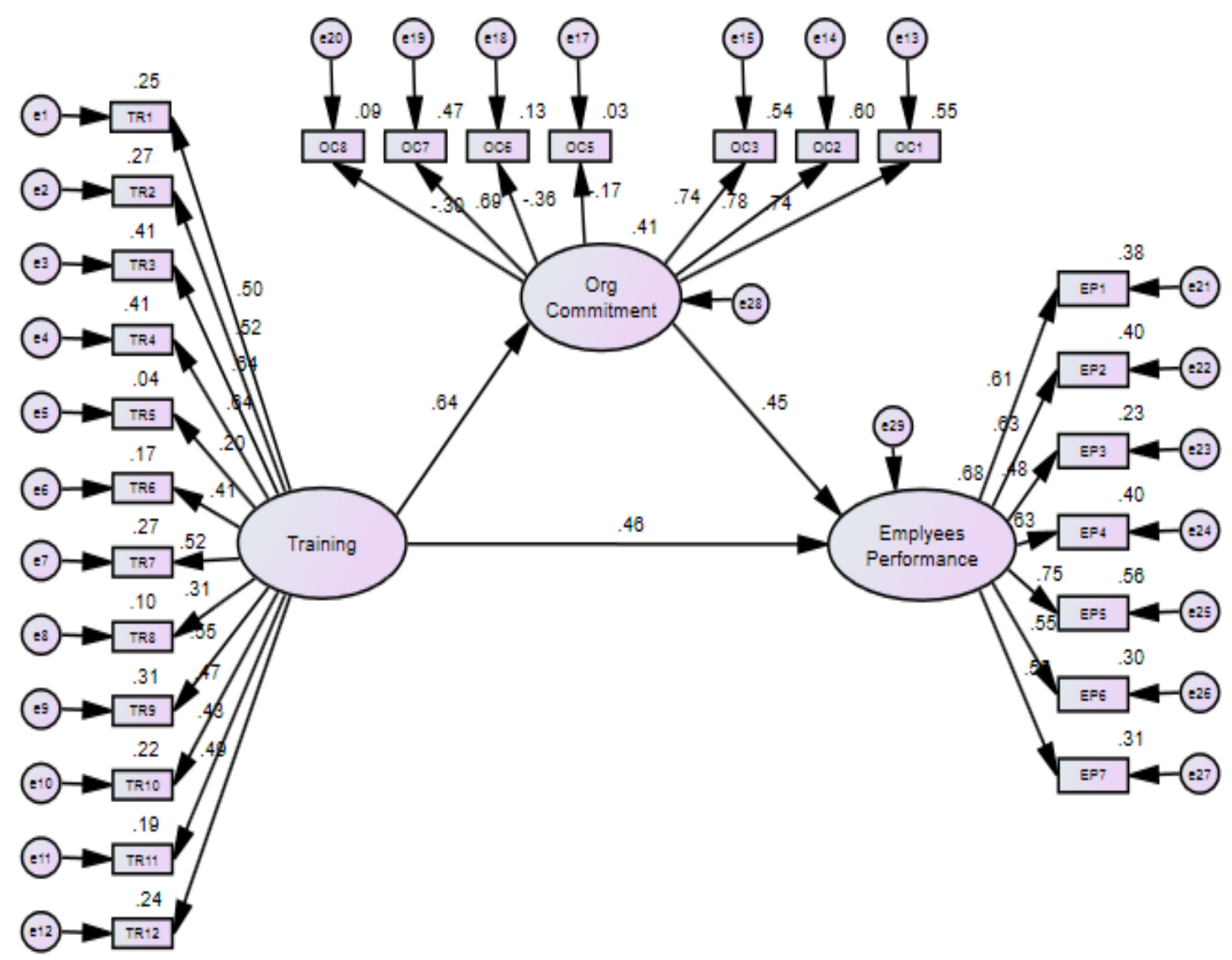

In order to test the hypotheses of the study, path coefficients of the direct relation of training and employee's performance were measured in table 4. To check the significance of direct, indirect and total effect, in analysis properties, Bootstrap Analyses with the default of 200 samples were measured and to calculate bias-corrected confidence intervals (CIs), level was set at 95 (Bollen \& Stine, 1992). 
Review of Economics and Development Studies, Vol. 6 (4) 2020, 867 - 879

Table 4: Path estimates of CFA structural model

\begin{tabular}{|l|l|l|l|l|}
\hline Parameter & Unstandardized $(\boldsymbol{\beta})$ & SE & t-value & Standardized (b) \\
\hline $\mathrm{H}_{1}: \mathrm{TR} \rightarrow \mathrm{EP}$ & $.59^{* * *}$ & .145 & 4.029 & .46 \\
\hline $\mathrm{H}_{2-\mathrm{i}}: \mathrm{TR} \rightarrow \mathrm{OC}$ & $1.25^{* * *}$ & .225 & 5.65 & .64 \\
\hline $\mathrm{H}_{2-\mathrm{ii}}: \mathrm{OC} \rightarrow \mathrm{EP}$ & $.29^{* * *}$ & .065 & 4.503 & .45 \\
\hline
\end{tabular}

$* * * \mathrm{p}<0.001$

Regarding the first hypothesis, $\mathrm{H}_{1}$, to investigate the direct effect of training on the employee's performance, the regression coefficient $(\beta)$ of "Training" was found 0.59. By studying the t-value against this regression coefficient, it was found that there was a significant direct effect of training on the employee's performance $(b=.462, \mathrm{p}<0.001)$. It means that 1 -unit increase in training increases 0.462 units $(46.2 \%)$ performance of employee. Further, to study the mediating role of affective organizational commitment, there were two sub hypotheses, i.e, $\mathrm{H}_{2-\mathrm{I}} \& \mathrm{H}_{2-\mathrm{ii}}$. The first part of the mediation was to investigate the direct effect of training on the organization commitment. The significant $\beta$ value $(1.25 * * *)$ showed that training had significantly direct effect on the organizational commitment $(b=.641, p<0.001)$. Moreover, the effect of affective organizational commitment on the employee's performance, as hypothesized in the $\mathrm{H}_{2-\mathrm{ii}}$, the regression coefficient $\beta(0.29 * * *)$ was found significant. The significant path coefficeint $(\mathrm{b}=.452, \mathrm{p}<0.001)$ indicated that to 1 -unit increase in affective organizational commitment, 0.452 units of the employee's performance increases (45.2\%). In order order to verify the second hypothesis of the study, i.e., mediation of affective organization commitment in the relationship of training and employee's performance (i.e., $\mathrm{H}_{2}$ : $\mathrm{TR} \rightarrow \mathrm{OC} \rightarrow \mathrm{EP}$ ), the direct, indirect and total effects were measured in table 5.

Table 5: Direct, indirect and total effects of Training on Employee's Performance

\begin{tabular}{|l|l|l|l|l|}
\hline \multirow{2}{*}{ Variables } & \multicolumn{3}{l|}{ Causal variables } & \multicolumn{2}{l|}{} \\
\cline { 2 - 5 } & Employee's Performance & Org. Commitment \\
\hline Training & Unstd. & St. & Unstd. & St. \\
\hline Direct Effect & $0.59^{*}$ & 0.46 & $1.25^{* *}$ & 0.64 \\
\hline Indirect Effect & $0.36^{*}$ & 0.29 & 0.00 & 0.00 \\
\hline Total Effect & $0.95^{*}$ & 0.75 & $1.25^{* *}$ & 0.64 \\
\hline & & & & \\
Org. Commitment & & & & \\
\hline Direct Effect & $0.29^{* *}$ & 0.45 & & \\
\hline Indirect Effect & 0.00 & 0.00 & & \\
\hline Total Effect & $0.29^{* *}$ & 0.45 & & \\
\hline
\end{tabular}

${ }^{*} \mathrm{p}<0.05 ;{ }^{* *} \mathrm{p}<0.01$

The $\beta$ value $\left(0.36^{*}\right)$ measuring indirect effect of training mediated through affective organizational commitment was found significant at $5 \%$ level of significance $\left(\beta_{1} \times \beta_{2}=1.25 \times 0.29=0.362\right)$. Hence, $\mathrm{H}_{2}$ : $\mathrm{TR} \rightarrow \mathrm{OC} \rightarrow \mathrm{EP}$ was accepted, that is, the affective organizational commitment significantly mediates the relationship between training and employee's performance $(b=0.29)$. Therefore, it can be concluded that though training significantly increase the employee's performance, however this effect further increases if mediated through the affective organizational commitment.

\section{Discussion}

The study was focused on investigating the mediating role of affective organizational commitment on the relationship between training of the employee and their performance. The demographic information showed that both male and female participants of the study were approximately equal in number and further their bifurcation according to their experience and training were also found gender balanced. 


\section{Review of Economics and Development Studies, Vol. 6 (4) 2020, 867 - 879}

Moreover, in the measurement model, the absolute and the incremental indices ensured the goodness-of-fit. However, the goodness-of-fit indices may further be improved, if the items of lower loadings would be removed from the model and rerun the model again. But as the loadings were significantly measuring their respective latent variables therefore, the structural model was proceeded.

In this research two hypotheses were formulated based on empirical evidence. Statistical tests CFASEM were used to test two main hypotheses of the study. The first hypothesis in the current research was to investigate the effect of training on the employee's performance in civil society organizations. The result illustrates that the training has significant and positive effect on the performance of the employees, especially in the case of civil society organizations. This finding of the current study is supported by the previous research study's findings (Hussain et al., 2020; Falola et al., 2014; Ahmed et al., 2014; Amin et al., 2013; Bulut \& Culha, 2010). The second hypothesis of the study was to investigate the mediating effect of the affective organizational commitment on the relationship between training and employee's performance. The results supported the significant mediation of the affective organizational commitment on this relationship. Moreover, it was also revealed that in the presence of the mediation direct effect of training remained significant on the employee's performance. The results are aligned with the previous researches of Mahmood (2012) and Dhar (2015). At the threshold of this discussion, the findings revealed that the training effect positively the employee's performance, whereas this positive effect even become strong if mediated through the affective organizational commitment in civil society organizations of Pakistan.

\section{Conclusion and Recommendations}

The present study was conducted to analyze the impact of training on the employee's performance with mediating role of affective organizational commitment in civil society organizations of Pakistan. This direct and indirect impact was found significant. Hence the results of the current study present that the training is a valuable strategic tool to enhance employee performance in civil society organizations of Pakistan. In CSOs, employees are mostly engaged in short term and multidimensional projects which need a specific skill set. Thus, to facilitate employees to perform their job-related tasks in an amicable way, employees should be provided with proper guidance through training. To overcome the gap between the assigned tasks and employee's qualification, the organization should arrange the training program according to the task specification. This would help to develop and maintain the sense of association and belongingness with the organization.

Moreover, from the theoretical point of view, current research findings contribute and broaden the earlier work conducted on training, employee performance and affective organizational commitment in the context of CSOs of Pakistan. For example, the fit indices of the measurement model of this study indicated that this model fit the data however, it may be further ameliorated by adding another variable supported by the theory and literature to improve it more, however it was not the main objective of the study, therefore, it may be taken as the recommendation for the future study.

Moreover, this study highlighted that the human resource practices are more beneficial for the organization and human resource as well. In the light of these results, rules and regulations can be developed and new policies may be formulated to make the training programs more effective and task oriented. For instance, conceptual trainings may increase the intellectual level of the employees which will enhance their performance. However, for the operative outcomes of training, content of training should be prepared effectively according to the need and the timings of training should be flexible. Thus, it is recommended that in order to build new abilities in the employees and to enhance their performances, civil society organizations should focus on Training Need Assessment (TNA) as an integral part. Regular and relevant training should be conducted periodically for quantitative evaluation, pre assessment and post assessment should also be conducted to measure the understanding level of the employees. 


\section{Review of Economics and Development Studies, Vol. 6 (4) 2020, 867 - 879}

\section{References}

Abbad. G., Borges-Andrade, J. E., \& Sallorenzo, L. H. (2004). Self-Assesment of training impact at work: Validation of a measurement scale. Interamerican Journal of Psychology, 38(2), 277284 .

Abbas, N. (2011). Towards a model of mathematics attitudes formation: Through the child's perception of social agents and self-beliefs. (PhD). Université de Strasboug, Strasbourg, France.

Abbas, N., Abrar ul Haq, M., Ashiq, U., \& Ubaid, S. (2020). Loneliness Among Elderly Widows and Its Effect on Social and Mental Well-being. Global Social Welfare, 7(3), 215-229. https://doi.org/10.1007/s40609-020-00173-5

Ahmad, N., Iqbal, N., Mir, M. S., Haider, Z., \& Hamad, N. (2014). Impact of Training and Development on the Employ Performance: A Case Study from Different Banking Sectors of North Punjab. Nigerian Chapter of Arabian Journal of Business and Management Review, 2, 19-24.

Allen, N. J., \& Meyer, J. P. (1990). The measurement and antecedents of affective, continuance and normative commitment to the organization. Journal of Occupational Psychology, 63(1), 118. https://doi.org/10.1111/j.2044-8325.1990.tboo506.x

Akhtar, J. (2014). Impact of Work Environment, Salary Package and Employees' Perception on Organizational Commitment: A study of Small \& Medium Enterprises (SMEs) of Pakistan. International Journal of Academic Research in Business and Social Sciences, 4(8), 147-165.

Alzalabani, \& Modi, (2014). Impact of human resources management practice and perceived organizational support on job satisfaction: evidence from Yanbu industrial city, KSA. IUP Journal of Organizational Behavior, 13(3), 33-52.

Amin. (2013). The Impact of Employees Training on the Job Performance in Education Sector of Pakistan. Middle-East Journal of Scientific Research, 17(9), 1273-1278.

Ameeq, A. \& Hanif, F. (2013). Impact of Training on Employee's Development and Performance in Hotel Industry of Lahore, Pakistan. Journal of Business Studies Quarterly, 4(4), 68-82.

Aragon, I. B., \& Valle, R. S. (2013). Does training managers pay off? International Journal of Human Resource Management, 24(8), 1671-1684. doi: 10.1080/o9585192.2012.725064

Bentler, P. M. (1990). Comparative fit indexes in structural models. Psychological Bulletin, 107, 238-246.

Bahoo , R., Nasim , I., Shaheen, R., \& Javed, M. L. (2020). A Confirmatory Factor Analysis of Interpersonal Teacher Behaviour Scale: Validation of the Urdu Translation of Secondary School Students' Perspectives. Review of Economics and Development Studies, 6(3), 715725. https://doi.org/10.47067/reads.v6i3.258

Bollen, K. A. (1989). Structural Equations with latent variables. New York: Wiley.

Bollen, K.A. (1990). Overall fit in covariance structure models: Two types of sample size effects. Psychological Bulletin, 107, 256-259

Bollen, K. A., \& Stine, R. A. (1992). Bootstrapping goodness-of-fit measures in structural equation models. Sociological Methods and Research, 21(2), 205-229.

Brum. (2007). What impact does training have on employee commitment and employee turnover? Schmidt Labor Research Center Seminar Research Series, 1-13.

Bulut, C., \& Culha, O. (2010). The effects of organizational training on organizational commitment. International Journal of Training and Development, 14(4), 309-322. https://doi.org/https://doi.org/10.1111/j.1468-2419.2010.0036o.x

Byrne, B. M. (2006). Structural Equation Modeling With EQS. New York: Routledge.

Chen, (2004). Examining the effect of organization culture and leadership behaviours on organizational commitment, job satisfaction, and job performance at small and middle- 


\section{Review of Economics and Development Studies, Vol. 6 (4) 2020, 867 - 879}

sized firms of Taiwan. The Journal of American Academy of Business, 5(2), 432-438.

Conway, E. (2004). Relating career stage to attitudes towards HR practices and commitment: Evidence of interaction effects? European Journal of Work and Organizational Psychology, 13(4), 417-446. https://doi.org/10.1080/13594320444000155

Dhar, R. L. (2015). Service quality and the training of employees: The mediating role of organizational commitment. Tourism Management, 46, 419-430.

Farooq, M., \& Khan, D. M. A. (2011). Impact of Training and Feedback on Employee Performance. Far East Journal of Psychology and Business, 5(2), 23-33. https://EconPapers.repec.org/RePEc:fej:articl:v:5a:y:2011:i:2:p:23-33

Falola, O. Osibanjo, A.O. \& OJO, S. O. (2014). Effectiveness of training and development on employee's performance and organization competitiveness in the Nigerian banking industry. Economic Science, 7(56), 161-170.

Folorunso, O. O., Adewale, A., \& Abodunde, S. M. (2014). Exploring the Effect of Organizational Commitment Dimensions on Employees Performance: An Empirical Evidence from Academic Staff of Oyo State Owned Tertiary Institutions, Nigeria. International Journal of Academic Research in Business and Social Sciences, 4(8), 275-286. https://doi.org/10.6007/IJARBSS/v4-i8/1096

Gardner, T. M., Wright, P. M., \& Moynihan, L. M. (2011). The impact of motivation, empowerment, and skill-enhancing practices on aggregate voluntary turnover: the mediating effect of collective affective commitment. Personnel Psychology, 64(2), 315-350. https://doi.org/https://doi.org/10.1111/j.1744-6570.2011.01212.x

Giangreco, A., Sebastiano, A., \& Peccei, R. (2009). Trainees' reactions to training: An analysis of the factors affecting overall satisfaction with training. The International Journal of Human Resource Management, 20(1), 96-111. https://doi.org/10.1080/o9585190802528417

Hair, J., \& Van der Leeuw, S. (2009). Multivariate Data Analysis. London: Prentice Hall, London.

Hertzog, M.A. (2008). Considerations in determining sample size for pilot studies. Research in Nursing \& Health, 31, 180-191.

Hill, R. (1998). What sample size is "enough" in internet survey research?. Interpersonal Computing and Technology: An Electronic Journal for the 21st Century, 6, 3-4.

Hussain, A. ., Khan, M. A., \& Khan, M. H. . (2020). The Influence of Training and Development on Organizational Commitment of Academicians in Pakistan. Review of Economics and Development Studies, 6(1), 43-55. https://doi.org/10.47067/reads.v6i1.183

Khan, F. (2011). Impact of training and feedback on employee performance. East Journal of Psychology and Business, 5(1), 23-33.

Kline, R. B. (2005). Principles and practice of structural equation modeling (2nd ed.). New York: Guilford Press.

Imran, A. (2012). Impact of Human Resource Practices on Organizational Commitment: A Study among Service Sector Employees in Pakistan. Interdisciplinary Journal of Contemporary Research in Business, 4(2), 81-90.

Isaac, S., \& Michael, W. B. (1995). Handbook in Research and Evaluation. San Diego, CA: Educational and Industrial Testing Services.

Jaros, S. (2007). Meyer and Allen Model of Organizational Commitment: Measurement Issues. The Journal of Organizational Behavior, 6(4), 1-25.

Jagero, N, Komba, H. V. \& Mlingi, M. N. (2012). Relationship between on the job training and employee's performance in courier companies in Dar es Salaam, Tanzania. International Journal of Humanities and Social Science, 22(2), 114-120.

Koc, M. (2014). Human Resource Management Practices, Job Satisfaction and Organizational Commitment. International Journal of Academic Research in Business and Social Sciences, 
4(9). 178-190.

Khan, M. S., Kundi, G. M., Khan, S., Khan, I., Khan, H., \& Yar, N. B. (2014). The Cause-\& Effect and Correlation between Job Satisfaction and Organizational commitment on Intention to leave among the Academicians in higher Educational Institutions of Khyber Pakhtunkhwa, Pakistan. International Journal of Academic Research in Business and Social Sciences, 4(2), 100-113.

Krishnaveni, R. Sujatha, K. (2012). Communities of Practice: An Influencing Factor for Effective Knowledge Transfer in Organizations. IUP Journal of Knowledge Management, 10(1), 2640.

Lamba, S., \& Choudhary, N. (2013). Impact of HRM Practices on Organizational Commitment of Employees. International Journal of Advancements in Research \& Technology, 4(2), 407423.

Liu, S. B. (2006). A study on the relationship between organizational commitment and working performance of life insurance salesmen in Taiwan. Unpublished master's thesis, Fujen Catholic University, Taiwan.

Mahmood, A. (2012). Impact of Training on Commitment, Retention and Performance Foundation University].

Islamabad http://prr.hec.gov.pk/jspui/bitstream/123456789/2763/1/1483S.pdf

Nda, M. M., \& Fard, R. Y. (2013). The Impact of Employee training and development on employee productivity. Global Journal Commerce and Management Perspective, 2(6), 91-93.

Restubog, S., Bordia, P., \& Tang, R. (2006). Effects of psychological contract breach on performance of IT employees. Journal of Occupational and Organizational Psychology, 79(2), 299-306. https://doi.org/https://doi.org/10.1348/o96317905X53183

Schumacker, R. E., \& Lomax, R. G. (2004). A beginner's guide to Structural Equation Modeling. Psychology Press.

Shahid, M., \& Ali, N. (2020). The Mediating Role of Psychological Capital and Organizatioanal Commitment between Work Environment and Job Bunrout. Review of Economics and Development Studies, 5(2), 381-386. https://doi.org/10.26710/reads.v5i2.624

Williams, L. J., \& Anderson, S. E. (1991). Job Satisfaction and Organizational Commitment as Predictors of Organizational Citizenship and In-Role Behaviors. Journal of Management, 17(3), 601-617. https://doi.org/10.1177/014920639101700305

Yeh, H., \& Chien, S. (2012). The Mediating Effect of Organizational Commitment on Leadership Type and Job Performance. The Journal of Human Resource and Adult Learning, 8(2), 5059. 